\title{
'Ortanique': A late-maturing tangor (Citrus sinensis $\times$ C. reticulata) with high carotenoid content
}

\author{
F.A. de Azevedo ${ }^{1, a}$, C. de Andrade Pacheco ${ }^{1}$, E. da Cruz Andrade ${ }^{1}$, E.H. Schinor ${ }^{2}$, M. Bastianel ${ }^{1}$, \\ M. Cristofani-Yaly ${ }^{1}$, P. Marluci da Conceição², F. Micheli ${ }^{3}$ and C. Dhuique-Mayer ${ }^{3}$ \\ ${ }^{1}$ Centro de Citricultura Sylvio Moreira, IAC, Anhaguera Highway, Km 158, 13490-970, Cordeirópolis, São Paulo State, Brazil \\ 2 Universidade Federal de São Carlos, Ufscar, Anhaguera Highway, Km 185, 13600-970, Cordeirópolis, São Paulo State, Brazil \\ ${ }^{3}$ CIRAD, Dept. Persyst, UMR QualiSud, Avenue Agropolis, 34398 Montpellier Cedex 5, France
}

\begin{abstract}
Summary
Introduction - The tangor cv. Ortanique presents positive characteristics for the fresh fruit export market, however little is known about this genotype in Brazil. In this study, we evaluated the ideal harvest time on two rootstocks, the fruit juice carotenoid content and possible postharvest storage of 'Ortanique' fruit. Materials and methods - The cultivar was grafted on 'Swingle' citrumelo and Poncirus trifoliata and was evaluated to the following variables: plant height, diameter and canopy volume, fruit physical and chemical quality [mass, soluble solids (SS), titratable acidity (TA) and the ratio (SS/TA)], production and productive efficiency in each graft combination. Carotenoids content of 'Ortanique' fruit juice grafted on 'Swingle' was qualified by HPLC. The optimal storage time of 'Ortanique' (with or without wax, stored at $10{ }^{\circ} \mathrm{C}$ or at room temperature) were determined for six weeks storage. Results and discussion - The rootstock 'Swingle' provided great growth and plant production of 'Ortanique' plants while Poncirus trifoliata delayed fruit maturation. The 'Ortanique' fruit juice contained high levels of $\beta$-cryptoxanthin and cis-violaxanthin and the fruit could be stored at $10{ }^{\circ} \mathrm{C}$ for six weeks without losing quality. Conclusion - The 'Ortanique' tangor has productive potential for commercial cultivation in Brazil, being late-maturing, its fruit high in carotenoid content and possibly well adapted to long storage for export.
\end{abstract}

\section{Keywords}

Brazil, mandarin, Citrus spp., rootstock, fruit physicochemical properties, postharvest management

\section{Résumé}

'Ortanique': une tangor à maturation tardive (Citrus sinensis $\times$ C. reticulata) à forte teneur en caroténoïdes.

Introduction - Le tangor 'Ortanique' présente des caractéristiques positives pour le marché d'exportation de fruits frais, mais peu de choses sont connues au sujet de ce génotype au Brésil. Dans cette étude, nous avons évalué le temps de récolte idéal sur deux porte-greffes, la teneur en caroténoïde des jus de fruits et le stockage éventuel de fruits 'Ortanique'

a Corresponding author: fernando@ccsm.br.

\section{Significance of this study}

What is already known on this subject?

- The 'Ortanique' tangor is produced commercially in several countries, such as Uruguay, Argentina and Spain, but little is known about the productive potential of the cultivar in Brazil.

What are the new findings?

- The productive efficiency of 'Ortanique' plants grafted on Poncirus trifoliata is high, when compared to the grafting on citrumelo rootstock 'Swingle'. In both cases 'Ortanique' is late-maturing in Brazilian conditions and its fruit juice has a high content of carotenoids.

What is the expected impact on horticulture?

- This cultivar presents a new option to extend the harvest period of tangerines in Brazil that is much concentrated in the middle of the year.

après la récolte. Matériel et méthodes - Le cultivar a été greffé sur le citrumelo 'Swingle' et Poncirus trifoliata et a été évalué selon les variables suivantes: hauteur de la plante, diamètre et volume de la canopée, qualité physique et chimique des fruits [masse, matières solubles (SS), acidité titrable (TA) et le rapport (SS/TA)], la production et l'efficacité productive dans chaque combinaison de greffage. La teneur en caroténoïdes du jus de fruit d"Ortanique' greffé sur 'Swingle' a été analysée par HPLC. L'optimum de stockage de l'Ortanique' (avec ou sans cire, stocké à $10^{\circ} \mathrm{C}$ ou à température ambiante) a été déterminé sur six semaines de conservation. Résultats et discussion - Le porte-greffe 'Swingle' a permis une croissance accrue et une production végétative des 'Ortanique' tandis que Poncirus trifoliata a retardé la maturation des fruits. Le jus des fruits d"Ortanique' contenait des niveaux élevés de $\beta$-cryptoxanthine et de cis-violaxanthine, et le fruit a pu être conservé à $10^{\circ} \mathrm{C}$ pendant six semaines sans perte de qualité. Conclusion - Le tangor 'Ortanique' a un fort potentiel productif en culture commerciale au Brésil, avec une maturation tardive, un contenu élevé des fruits en caroténoïdes et sans doute bien adapté à un long stockage pour l'exportation. 


\section{Mots-clés}

Brésil, mandarine, Citrus spp., porte-greffe, propriétés physico-chimiques des fruits, gestion post-récolte

\section{Introduction}

In Brazil, citrus production essentially includes sweet orange [Citrus sinensis (L.) Osbeck], where mandarin represents only $6 \%$ of the total production. Among the cultivars of tangerine, the most cultivated are: 'Ponkan' mandarin ( $C$. reticulata Blanco) and 'Murcott' tangor [C. sinensis (L.) Osbeck $\times C$. reticulata Blanco]. There are few plantations of willow leaf mandarin (C. delicious Tenore) and 'Cravo' mandarin (C. reticulata Blanco) (IBGE, 2012). None of these cultivars meet the internationally accepted standard of fruit seedless. The citrus consumers seek fruits with different flavors, size and colors, attractive shapes, ease of peeling, long shelf life and no chemical residues (Pio, 2003).

Therefore, the Centro APTA Citros Sylvio Moreira of Instituto Agronômico, from Brazil, selected cultivars seedless with export potential, such as the 'Nules' clementine (C. clementine), the 'Nova' tangelo [C. clementine $\times(C$. paradise $\times$ C. tangerine)] and the 'Ortanique' tangor [C. reticulata Blanco $\times$ C. sinensis (L.) Osbeck].

The 'Ortanique' tangor is a natural hybrid of the tangerine with orange, produces fruit late-maturing and seedless. It is grown in many regions of the world, such as Honduras, Australia, Cyprus and South Africa (Saunt, 1990). Selecting cultivars that have late maturing is one of the major objectives of the breeding program, because a reduction in the tangerine supply has occurred in Brazil (Bastianel et al., 2014).

In Brazil, due to botanical and historical reasons, a small number of rootstocks are used in citrus commercial plantations (Mourão-Filho et al., 2008). In addition, the use of the same rootstock to different canopy cultivars, probably does not meet the specific characteristics of each cultivar, preventing the plant to show its full productive potential (Pompeu Júnior et al., 2002).

Citrus consumption has been associated with lower risks of certain cancers and cardiovascular disease (Aviram et al., 2008). Although the antioxidant capacity of citrus juice is mainly associated with the soluble fraction containing polyphenols and vitamin $\mathrm{C}$, a greater polar fraction including carotenoids can also contribute to the juice antioxidant capacity, which leads to protective effects against degenerative diseases. Certain carotenoids present in citrus have been detected in human plasma: $\beta$ - and $\alpha$-carotenes, lycopene, $\beta$-cryptoxanthin, lutein and zeaxanthin. The last two, lutein and zeaxanthin, are present in higher levels in oranges; tangerines stand out by having high levels of $\beta$-cryptoxanthin and $\beta$-carotene. $\beta$-cryptoxanthin, present in high concentrations in tangerine juice, largely contributes to bright orange juice and is the main precursor of pro-vitamin A.

For export, an important consideration is the quality post-harvest, mainly storage (cold). Refrigerated storage is considered the most effective method for preserving fruit quality, as it slows aging and decreases respiration, maturation, decay incidence and undesirable metabolic changes (Cuquerella and Navarro, 1989).

Thus, the aim of this study was to evaluate the production and physicochemical qualities of the 'Ortanique' fruit cultivar grafted on two rootstocks, quantify the carotenoids present in the juice, and observe possible changes in the physicochemical characteristics under different storage conditions (temperatures).

\section{Materials and methods}

Tests were developed to cultivate 'Ortanique' tangor [Citrus reticulata Blanco $\times$ C. sinensis (L.) Osbeck] due to the late ripening of its fruits and its seedlessness. The orchard was planted in 2000 in the city of Cordeirópolis, SP, with plants grafted on 'Swingle' citrumelo (C. paradisi Macfad $\times$ Poncirus trifoliata L. Raf.) and $P$. trifoliata at a spacing of $7 \times 4 \mathrm{~m}$, with ten repetitions of each combination in a randomized block design.

\section{Vegetative growth and productivity}

The height and the diameter of the 'Ortanique' tangor were monitored for two years (2009 and 2010). The measurements were made with a graduated wooden ruler, measuring parallel with the growth axis (height) and parallel to the ground at a height of $1.5 \mathrm{~m}$ (diameter) for ten plants per combination. The canopy volume (V) was determined based on the following equation: $V=2 / 3 \pi R^{2} H$, where $R$ is the mean radius of the canopy and $H$ is the height of the plant.

To evaluate the production, the fruits were harvested in October of each year, where all the fruits were collected from 10 plants per combination. The production was measured by directly weighing the fruit on a scale with a capacity of $100 \mathrm{~kg}$. From this quantity, the production efficiency ( $\mathrm{kg}$ fruit $\mathrm{m}^{-3}$ ) was calculated by the plant production $(\mathrm{kg})$ per canopy volume $\left(\mathrm{m}^{-3}\right)$ ratio. These assessments were conducted in 2009 and 2010, when the trees were adult with 9 and 10 years old, respectively.

\section{Physicochemical properties of the fruit}

The physical and chemical analyses of the fruit were conducted monthly from June to November in 2010, corresponding to 9 to 14 months after anthesis, and the maturation curve was determined from the results. Fruits were collected for analysis in the outer portion of the trees between 1.0 and $2.0 \mathrm{~m}$ above ground level and throughout the perimeter of the plant; resulting in a total of 5 samples containing 10 fruits each. The fruits were sent to the Laboratory Quality and Post-Harvest Centro APTA Citros Sylvio Moreira/IAC, Brazil. The following determinations were measured:

- Soluble solids (SS) were determined by a direct reading on a B \& S refractometer, RFM model 330. The data were corrected by temperature and acidity of the juice.

- Titratable acidity (TA) was obtained by titrating $25 \mathrm{~mL}$ juice with a 0.3125 normal sodium hydroxide solution phenolphthalein was used as an indicator.

- The Soluble solids/Acidity ratio (SS/TA) was calculated in order to indicate the maturity stage of citrus.

\section{Juice carotenoid content}

A fine biochemical analysis was performed to quantify the carotenoid in the fruit juice of 'Ortanique' 'Murcott' grafted onto 'Swingle' citrumelo. These fruits were collected during the 2013-14 cropping season (in October 2014), and the experiment was conducted in the municipality of Cordeirópolis/SP, Brazil. The quantification of carotenoids was performed using HPLC according to Dhuique-Mayer et al. (2005) at the Laboratory of Carotenoids and HPLC/MS, UMR Qualisud, Dept. Persyst at CIRAD, France.

Ten $\mathrm{mL}$ of 'Ortanique' tangor juice were extracted, and $35 \mathrm{~mL}$ solvent (4/3 [v/v] ethanol/hexane) 0.1\% BHT, $100 \mathrm{mg}$ $\mathrm{MgCO}_{3}$ and $500 \mu \mathrm{L}$ standard lycopene internal (uncontrolled [c]) were added. This mixture was stirred for 5 min after a filtration using a number-2 synthetic filter. Ethanol and hexane were successively used to wash the residue, i.e., $30 \mathrm{~mL}$ of eth- 
anol was used, followed by $30 \mathrm{~mL}$ hexane and another $30 \mathrm{~mL}$ hexane. After these three successive extractions, the extract was placed in a separatory funnel, and $50 \mathrm{~mL}$ of $10 \% \mathrm{NaCl}$ was added. The aqueous phase was removed, whereas the organic phase was washed three times with distilled water and then dried with anhydrous sodium sulfate. The resulting extract was then filtered through a number- 2 synthetic filter and subjected, in sequence, to a Rotavapor $\left(37^{\circ} \mathrm{C}, 100 \mathrm{mbar}\right)$ until complete dryness. The residue was dissolved in $0.5 \mathrm{~mL}$ dichloromethane and $1 \mathrm{~mL}$ of a MTBE/MeOH (80:20) mixture and then analyzed using HPLC.

The lycopene area $(\mathrm{mAU} * \mathrm{~s})$ extracted from the sample and standard lycopene area provided by a sample of the same amount ( $500 \mathrm{uL}$ ) were compared, dried under nitrogen flow and dissolved in $0.5 \mathrm{~mL}$ dichloromethane and $1 \mathrm{~mL}$ of the MTBE/MeOH (80:20) mixture. The dilution was made to the track/scale of analysis.

\section{Postharvest}

For the postharvest test, a collection of fruits of the 'Murcott' 'Ortanique' grafted on 'Swingle' citrumelo were studied with regard to the maturation period (October 2010). Then, the fruits were subjected to surface cleaning, subsequently dried and subjected to storage. The fruits were initially divided into two samples, one of which was subjected to the application of wax, which is commercially used and contains a fungicide (UE wax Citrosol 16\% + $4 \mathrm{~mL}$ Imazalil) to avoid the typical development of postharvest pathogens. The application consisted of immersing each fruit in the wax solution with water, reproducing what is done in packing houses. The fruits were then dried and stored. The following two samples were subdivided and stored at different temperatures: a) a cold chamber at $10{ }^{\circ} \mathrm{C}$ and $90 \%$ relative humidity (RH) and, b) at room temperature $\left(19.7-21.5{ }^{\circ} \mathrm{C}\right.$ and $68.8-71.4$ $\mathrm{RH}$ ).

The physical and chemical analyses were performed weekly for 42 days (six weeks) to monitor the internal and external changes of the fruit according to the method described above. The experiment was completely randomized in a factorial scheme $(6 \times 2 \times 2)$ : six weeks, two types of storage, and fruits with and without wax, with four replications composed of five fruits each.

\section{Statistical analysis}

The plant height, diameter, volume and production and productive efficiency data were subjected to analysis of vari- ance and then compared (Duncan test, $P>5 \%$ ). A regression analysis was performed for the physical and chemical quality values, and the model selected for each variable was based on the significance of the parameters and $\mathrm{R}^{2}$ values.

\section{Results and discussion}

\section{Vegetative growth and productivity}

The average plant height ranged from 2.0 to $3.1 \mathrm{~m}$, and the canopy volume ranged from 6.1 to $13.3 \mathrm{~m}^{3}$; the 'Swingle' citrumelo rootstock provided greater vegetative growth than the Poncirus trifoliata (Table 1). Other studies comparing these rootstocks in citrus cultivars, such as 'Montenegrina' tangerine (Toniolli et al., 1993), have also found 'Swingle' citrumelo to have the most developed plants. Brugnara et al. (2009) also reported that the trifoliate provides less volume in the canopy 'Michal' tangerine in Rio Grande do Sul than more vigorous rootstocks such as 'Rangpur' lime or 'Swingle' citrumelo.

In the two years of evaluation, the 'Swingle' citrumelo provided a greater production of 'Ortanique' fruit per tree (kg plant-1); however, the high productive efficiency in 2009 of plants grafted onto Poncirus trifoliata (Table 1) is notable. This characteristic of trifoliate orange of producing higher yield was also reported by Stuchi et al. (2003) evaluating acid lime cv. Tahiti. Schäfer et al. (2001) also reported the direct influence of rootstock vigor on the scion and, consequently, in production. According to the authors, the Poncirus trifoliata carries in general less force on the canopy compared with, for example, the Rangpur lime.

A major advantage of $P$. trifoliata was its dwarfing characteristic because rootstocks in the modern citrus industry with this characteristic have a tendency for high density plantations in citrus groves (Stuchi et al., 2003; Schinor et al., 2013); a potential example is the Flying Dragon trifoliate. According to the classification of Bitters et al. (1979), cultivation of 'Ortanique' should be considered semi-dwarf plants in relation to established standards (sweet orange, 'Rangpur' lime and 'Troyer' citrange) especially when grafted onto $P$. trifoliata, for which a reduction of up to $50 \%$ of the canopy is observed relative to these standards. In this study, a reduction of approximately $42 \%$ in the size of the crown was observed compared with the 'Swingle' citrumelo.

Less vigorous plants, such as 'Ortanique' tangor, bring a number of advantages over vigorous plants because a small plant is a more efficient production unit: controlling pests

TABlE 1. Height, diameter, volume, production and production efficiency of 'Ortanique' tangor plants grafted onto 'Swingle' citrumelo or Poncirus trifoliata (Cordeirópolis, Sao Paulo State, Brazil, 2009-2010).

\begin{tabular}{lccccc}
\hline Rootstocks & $\begin{array}{c}\text { Plant } \\
\text { height } \\
(\mathrm{m})\end{array}$ & $\begin{array}{c}\text { Plant } \\
\text { diameter } \\
(\mathrm{m})\end{array}$ & $\begin{array}{c}\text { Canopy } \\
\text { volume } \\
\left(\mathrm{m}^{3}\right)\end{array}$ & $\begin{array}{c}\text { Fruit } \\
\text { production } \\
\left(\mathrm{kg} \mathrm{plant}^{-1}\right)\end{array}$ & $\begin{array}{c}\text { Production } \\
\text { efficiency } \\
\left(\mathrm{kg} \mathrm{m}^{-3}\right)\end{array}$ \\
\hline & & & 2009 & & \\
\hline 'Swingle' citrumelo & $2.49 \mathrm{a}^{*}$ & $3.11 \mathrm{a}$ & $12.60 \mathrm{a}$ & $78.55 \mathrm{a}$ & $6.23 \mathrm{~b}$ \\
Poncirus trifoliata & $2.02 \mathrm{~b}$ & $2.41 \mathrm{~b}$ & $6.13 \mathrm{~b}$ & $59.39 \mathrm{~b}$ & $9.70 \mathrm{a}$ \\
CV (\%) & 6.83 & 9.48 & 16.75 & 13.39 & 39.68 \\
\hline & & & 2010 & & $69.67 \mathrm{a}$ \\
\hline 'Swingle' citrumelo & $2.56 \mathrm{a}$ & $3.12 \mathrm{a}$ & $13.21 \mathrm{a}$ & $5.34 \mathrm{~b}$ \\
Poncirus trifoliata & $2.08 \mathrm{~b}$ & $2.53 \mathrm{~b}$ & $6.97 \mathrm{~b}$ & $43.33 \mathrm{~b}$ & $6.22 \mathrm{a}$ \\
CV (\%) & 7.79 & 4.38 & 22.4 & 23.25 & 28.49 \\
\hline
\end{tabular}

${ }^{*}$ Means followed by the same letter in the column for each year, not significantly different (Duncan's test, $\left.P<0.05\right)$.

$\mathrm{CV}$ : coefficient of variation. 
and diseases is more effective and economical, harvesting is more readily facilitated and consequently cheaper (Duncan et al., 1979), and the grower can densify planting, considerably increasing the number of plants per hectare. This densification is desirable and necessary to increase the production per unit area available and, consequently, the profitability (Stuchi et al., 2003). Some problems associated with a high density of plants per area are high initial costs to purchase seedlings and the need for annual pruning, as well as establishment of the orchard.

\section{Physical-chemical quality of the fruits}

Regarding fruit ripening of the 'Ortanique' cultivar, the soluble solids, acidity and Ratio of juice data, was considered.

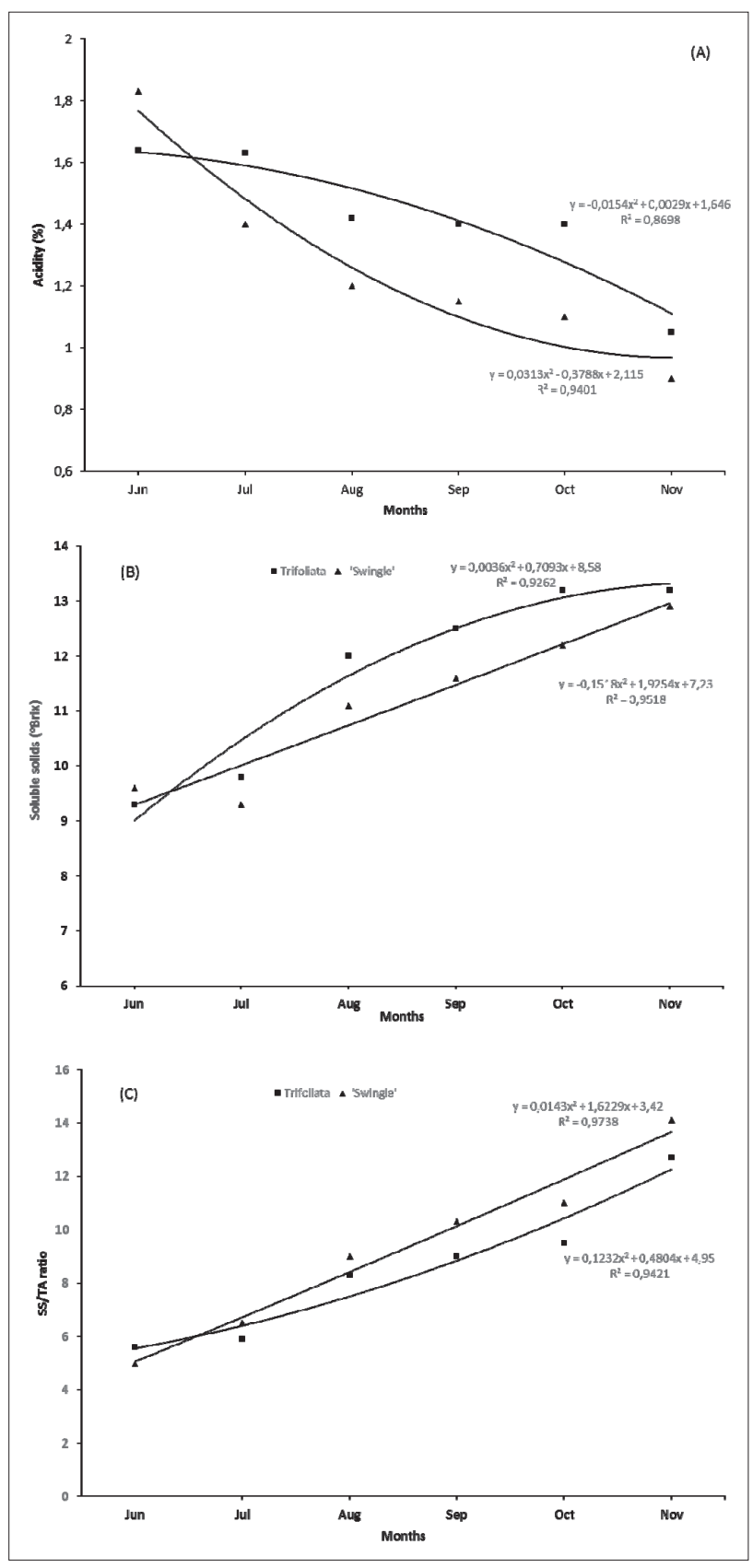

FIGURE 1. Titratable acidity - TA (A) soluble solid content SS (B) and SS/TA ratio (C) of the juice of 'Ortanique' tangor fruit grafted onto 'Swingle' citrumelo and Poncirus trifoliata for six months (Cordeirópolis, Sao Paulo State, Brazil, from June to November, 2010).
The two combinations proved to be late mature and can be harvested from mid-October to November. Fruits harvested on the trees grafted on 'Swingle' citrumelo, ripen up earlier, reaching soluble solids and Ratio values greater than the trifoliate on a few dates (June and September), with an earlier initial point of harvest in mid-September (Figure 1C). Borges and Pio (2003) observed that when this cultivar was planted under the conditions found in Capão Bonito, in the southwest region of São Paulo, Brazil, the maturation period was August and September.

As for the content of soluble solids (SS) (Figure 1A), there is an inversion in the juice ratio, where the combination in the trifoliata fruit is higher than in the 'Swingle' rootstock on three dates (during July to September). This reversal can be explained by a lower percentage of acidity observed in the combination in citrumelo (Figure 1B). Similar results were observed by Stenzel et al. (2003), who reported higher SS concentrations in 'Ponkan' grafted onto P. trifoliata as well as Gonzatto et al. (2011), who showed higher levels of SS and TA in fruits from Oneco tangerine (species) grafted onto trifoliate Flying Dragon. Cantuarias-Avilés et al. (2010) argue that the highest quality fruit is directly related to a high SS content, leading to a high Ratio.

The differences identified above in the SS and TA values of the combinations studied resulted in higher Ratio values for the fruit juice from grafted 'Swingle' citrumelo. The SS/ TA indicates the maturation and harvest, an important feature in citrus cultivars. On the Brazilian fresh fruit market, according to the CEAGESP Table citrus classification (2011), the minimum ratio value for commercializing 'Murcott' tangor is 10. Adopting this value for 'Ortanique', which is also a 'Murcott', the fruit could be harvested in September when grafted onto 'Swingle' and subjected to the conditions of Cordeirópolis, Sao Paulo State, Brazil.

While considering the ratio SS/TA $=10$ to start harvesting the Murcott group fruit, it is notable that values of $\approx 12$ are highly preferred by Brazilian consumers. Therefore, this value could increase the 'Ortanique' cultivar's quality and acceptance by the market until the month of October and extending through November for those coming from the plants grafted onto Poncirus trifolita, which proved to be a later combination. Entering the market outside the traditional time for mandarins grown in the state of São Paulo creates a commercial advantage.

\section{Juice carotenoid content}

The major dietary carotenoids characterized by saponified extracts in 'Ortanique' tangor were $\beta$-cryptoxanthin and cis-violaxanthin, a yellow xanthophyll (Figure 2 ), with $\beta$-cryptoxanthin the most abundant nutritional carotenoid $\left(7.68 \mathrm{mg} \mathrm{L}^{-1}\right)$. These results are in agreement with Dhuique-Mayer et al. (2005) and other authors from Asian countries (Lin et al., 1995; Sumida et al., 1999; Ko et al., 2000), who reported the presence of dietary carotenoids in mandarins, especially $\beta$-cryptoxanthin, provita$\min \mathrm{A}$, considered as the main carotenoid.

Dhuique-Mayer et al. (2005) analyzed the main components of oranges, clementines and mandarins and managed to classify these fruit based on their nutritional criteria (carotenoids content), into three different categories: Category 1 included clementines and tangerines and were clearly distinguished from the categories of sweet orange (categories 2 and 3 ) to be highly correlated with the contents of $\beta$-cryptoxanthin (8.63-10.70 $\mathrm{mg} \mathrm{L}^{-1}$ ) and $\beta$-carotene (1.45-1.60 $\mathrm{mg} \mathrm{L}^{-1}$ ). Category 2 included 'Salustiana' oranges, 'Hamlin', 'Maltaise' and 'Shamouti' and contained the lowest levels of $\beta$-cryptox- 


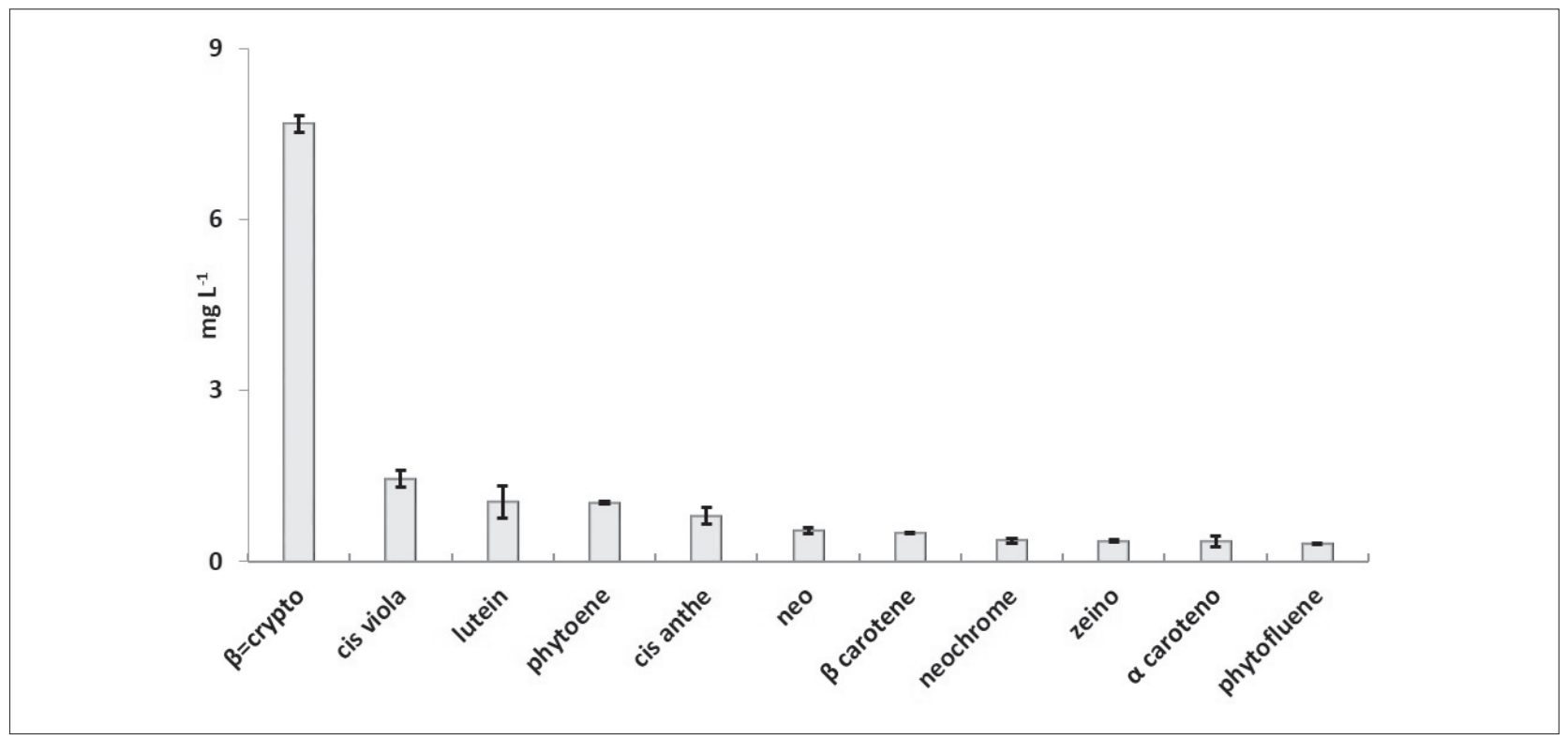

FIGURE 2. Carotenoid content ( $\mathrm{mg} \mathrm{L}^{-1}$ ) in juice extracted from 'Ortanique' tangor fruit grafted onto 'Swingle' citrumelo, from the experiment installed in Cordeirópolis, Sao Paulo State, Brazil (CIRAD/Qualisud, Montpellier, France, May 2014). $\beta$ crypto: $\beta$-cryptoxanthin; cis violate: cis violaxanthin; cis anthe: cis antheroxantin; neo: neoxanthin; zeino: zeinoxantin.

anthin (1.35-2.76 $\left.\mathrm{mg} \mathrm{L}^{-1}\right)$ and $\beta$-carotene $\left(0.10-0.25 \mathrm{mg} \mathrm{L}^{-1}\right)$ while being more correlated with lutein content $(0.50-0.72$ mg L-1). Category 3 contained 'Sanguinelli' oranges, 'Valencia' and 'Pera', because of their similar levels of $\beta$-cryptoxanthin (1.65-3.88 $\left.\mathrm{mg} \mathrm{L}^{-1}\right)$ and $\beta$-carotene $\left(0.30-0.45 \mathrm{mg} \mathrm{L}^{-1}\right)$, which were higher than those of the oranges in category 2.

However, in this work and other work mentioned above, $\beta$-cryptoxanthin mainly in the form of retinyl ester (Brody, 1994) proved to be the main pro-vitamin A. Thus, this study agrees with Gancel et al. (2003), who observed a strong correlation between $\beta$-cryptoxanthin and hesperidin in the tangerine group, in their study, encompassing clementines, showing that the clementine, a Mediterranean mandarin hybrid (Citrus deliciosa Tenore) with sweet orange [Citrus sinensis (L.) Osbeck], are more influenced by the secondary metabolites from their parental tangerine than their parental orange. This reveals tangerines as an interesting parent for the breeding of citrus with respect to a high nutritional value and genetic dominance. Similarly, the 'Ortanique' tangor also showed a high $\beta$-carotene content $\left(0.50 \mathrm{mg} \mathrm{L}^{-1}\right)$ and, in addition to $\beta$-cryptoxanthin, $\beta$-carotene also influences the delivery of pro-vitamin A in this citrus cultivar.

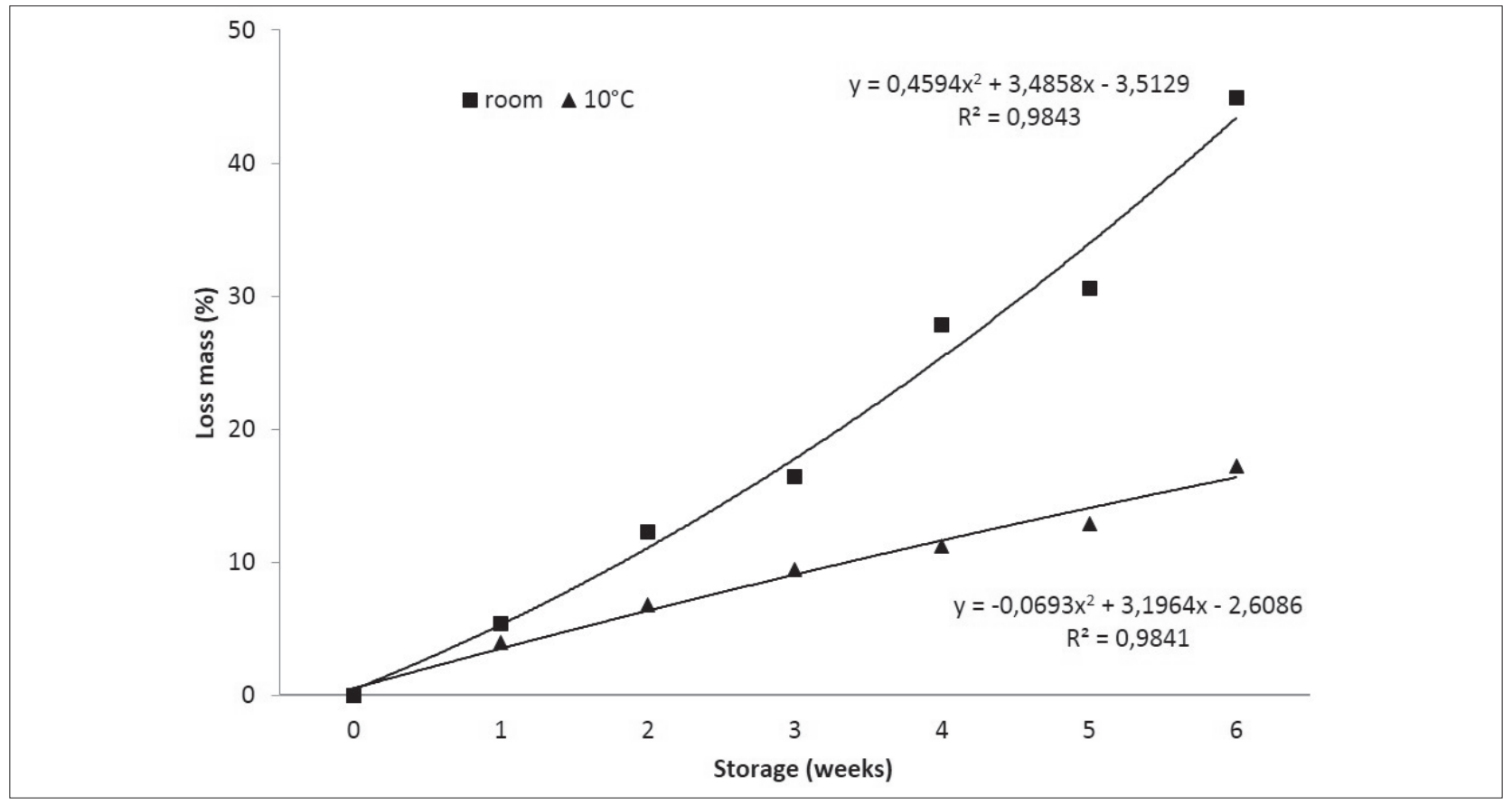

FIGURE 3. Mass loss of 'Ortanique' tangor fruit, stored at room temperature and $10^{\circ} \mathrm{C}$ for six weeks (Cordeirópolis, Sao Paulo State, Brazil, 2010). 


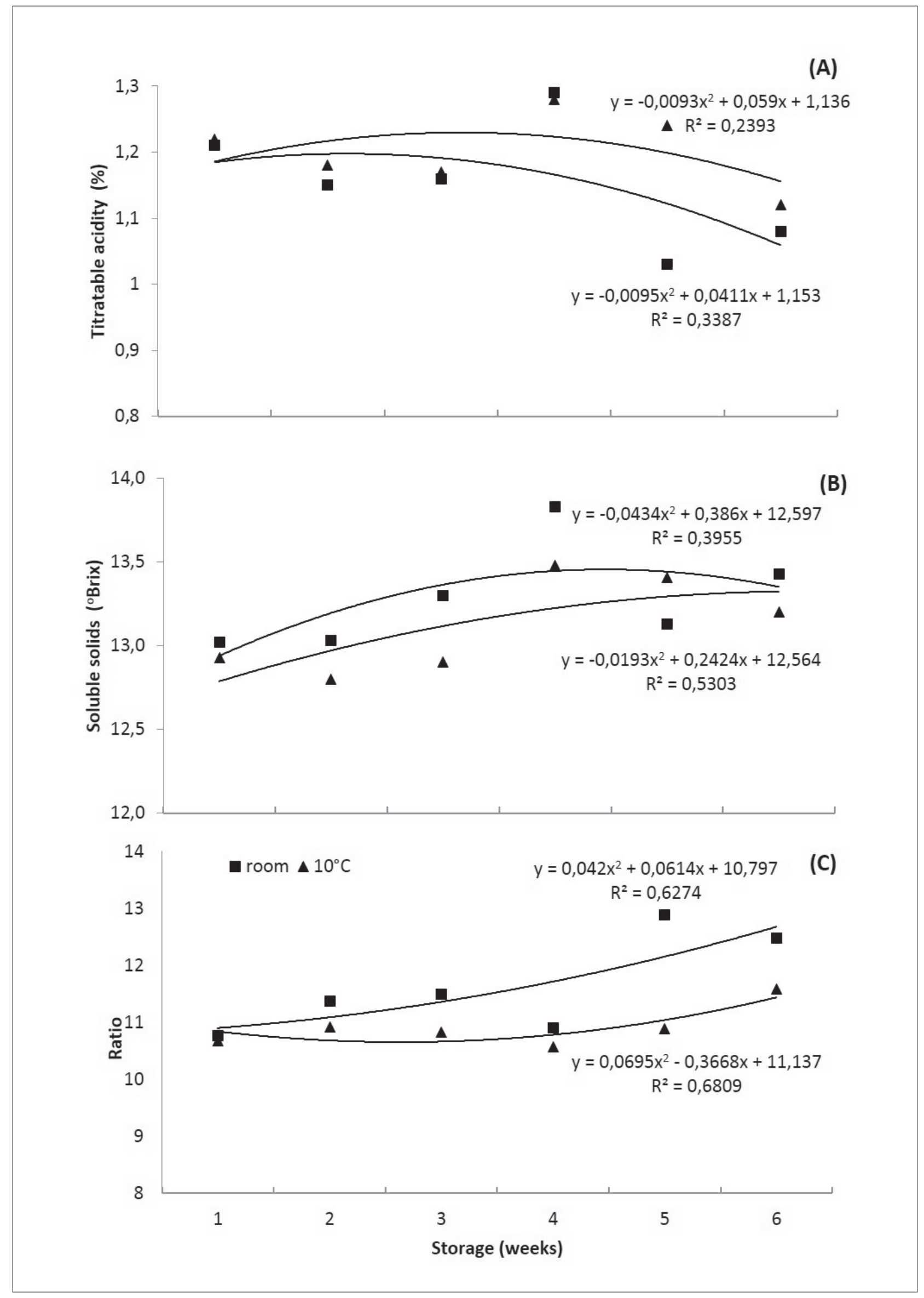

FIGURE 4. Titratable acidity - TA (A), soluble solid content - SS (B) and SS/TA ratio (C) of the juice from 'Ortanique' tangor, stored at room temperature and $10^{\circ} \mathrm{C}$ for six weeks (Cordeirópolis, Sao Paulo State, Brazil, 2010). 


\section{Postharvest}

In the postharvest test, waxing did not influence the physical and chemical characteristics of the 'Ortanique' tangor fruit. There was major mass loss, as was expected, for the fruits stored at room temperature, resulting in $44.9 \%$ by 42 days ( $6^{\text {th }}$ week). The fruits subjected to cold room storage had a significantly lower percentage mass loss at 28 days (fourth week) when compared to room temperature storage, and at 42 days losses of $17.2 \%$ (Figure 3 ). This is due to the transpiration of water eliminated due to the vapor pressure difference between the fruit and the air in the environment, as in a refrigerated environment. The lower temperature reduces the metabolism and, consequently, the fruit loses less mass (Jeronimo and Kanesiro, 2000).

There was a reduction in TA levels during the storage, and it was more pronounced when the fruits were stored at room temperature. The opposite occurred with the SS content. The fruits stored in a cold room $\left(10^{\circ} \mathrm{C}\right)$ showed no significant changes in the SS/TA values, while storage at room temperature showed significant increases over time, in the ratio related to fruit juice characteristics (Figure $4 \mathrm{~A}-\mathrm{C}$ ).

One explanation for the small variations in the SS is that weight loss during storage contributes to the concentration of sugars. Citrus fruits are non-climacteric fruit, so harvesting them with the correct maturity is essential to obtaining quality fruit (Pereira et al., 2006). A decrease in TA was also reported by Malgarim et al. (2008), who studied the post-harvest quality of 'Nova' tangelo $(C$. reticulata Blanco $\times$ C. paradisi Macfad) during different periods of storage. After harvest and during storage, the concentration of organic acids tended to decline in most of the fruit, due to these compounds as respiratory substrates and carbon skeletons to synthesize new compounds.

Increases in the ratio values were observed during storage (Figure 4) and were also reported by Lima et al. (1999), who studied the fruit quality of 'Ponkan' tangerines stored at room temperature. The SS/TA ratio is an important parameter in evaluating the quality of fruit during ripening, and this ratio tends to increase due to decreased acids and increased sugars (Chitarra and Chitarra, 1990). According to Baldwin (1993), a ratio SS/TA $=8-10$ is accepted as a minimum maturity index for citrus, and in the 'Ortanique' tangor fruit, this ratio fluctuated between 10.58 and 12.88 during the days of storage.

\section{Conclusion}

The 'Swingle' citrumelo rootstock provides increased vegetative growth to the 'Ortanique' tangor, while the trifoliate induces later maturation. The juice of the 'Ortanique' 'Murcott' fruit has high $\beta$-cryptoxanthin and $\beta$-carotene content, and storage at $10{ }^{\circ} \mathrm{C}$ maintains the fruit quality for at least six weeks after harvest, enabling the export of this variety.

\section{References}

Aviram, M., Dornfeld, L., Rosenblat, M., Volkova, N., Kaplan, M., Coleman, R., Hayek, T., Presser, D., and Fuhrman, B. (2000). Pomegranate juice consumption reduces oxidative stress, atherogenic modifications to LDL, and platelet aggregation: studies in humans and in atherosclerotic apolipoprotein E-deficient mice. Am. J. Clin. Nutr. 71, 1062-1076.

Baldwin, E.A. (1993). Citrus fruit. In Biochemistry of Fruit Ripening, J.E. Taylor, G.A. Tucker, and G.B. Seymour, eds. (London: Chapman and Hall), p. 255-271. https://doi.org/10.1007/978-94-011-15841 4.
Bastianel, M., Simonetti, L.M., Schinor, E.H., Giorgi, R.O., De Negri, J.D., Gomes, D.N, and Azevedo, F.A. (2014). Avaliação do banco de germoplasma de mexericas com relação a características físicoquímicas e suscetibilidade à mancha marrom de alternária. Bragantia 73, 23-33. https://doi.org/10.1590/0100-5405/2191.

Bitters, W.P., Cole, D.A., and McCarty, C.D. (1979). Facts about dwarf citrus trees. Citrograph 64, 54-56.

Borges, R.S., and Pio, R.M. (2003). Comparative study of the mandarin hybrid fruit characteristics: 'Nova', 'Murcott' and 'Ortanique' in Capão Bonito SP, Brazil. Rev. Bras. de Fruticult. 25, 448-452. https:// doi.org/10.1590/S0100-29452003000300022.

Brody, T. (1994). Nutritional Biochemistry (San Diego: Academic Press), p. 400-409.

Brugnara, E.C., Schwarz, S.F., Koller, O.C., Bender, R.J., Weiler, R.L., Gonzatto, M.P., Schäfer, G., Martins, F.T., and Lima, J.G. (2009). Porta-enxertos para a tangerineira 'Michal' no Rio Grande do Sul. Ciência Rural 39, 1374-1379. https://doi.org/10.1590/S010384782009005000068 .

Cantuarias-Avilés, T., Mourão Filho, F.A.A., Stuchi, E.S., Silva, S.R., and Espinoza-Nunez, E. (2010). Tree performance and fruit yield and quality of 'Okitsu' Satsuma mandarin grafted on 12 rootstocks. Sci. Hortic. 123, 318-322. https://doi.org/10.1016/j. scienta.2009.09.020.

CEAGESP. Companhia de Entrepostos e Armazéns Gerais de São Paulo (2011). Normas de classificação de citros de mesa. (São Paulo, Brasil: Ceagesp).

Chitarra, M.I.F., and Chitarra, A.B. (1990). Pós-colheita de frutos e hortaliças: fisiologia e manuseio. (Lavras: ESAL/FAEPE).

Cuquerella, J., and Navarro, P. (1989). Estado actual de la frigoconservación de los cítricos. Fruticult. Profes. 25, 122-129.

Dhuique-Mayer, C., Caris-Veyrat, C., Ollitrault, P., Curk, F., and Amiot, M.J. (2005). Varietal and interspecific influence on micronutrient contents in citrus from the Mediterranean area. J. Agric. and Food Chem. 53, 2140-2145. https://doi.org/10.1021/jf0402983.

Duncan, J.H., Sproule, R.S., and Bevington, K.B. (1978). Commercial application of virus-induced dwarfing. Proc. Int. Soc. of Citricult. 317-319.

Gancel, A.L., Ollitrault, P., Froelicher, Y., Tomi, F., Jacquemond, C., Luro, F., and Brillouet, J.M. (2003). Leaf volatile compounds of seven citrus somatic tetraploid hybrids sharing willow leaf mandarin (Citrus deliciosa Ten.) as their common parents. J. Agric. and Food Chem. 51, 6006-6013. https://doi.org/10.1021/jf0345090.

Gonzatto, M.P., Kovaleski, A.P., Brugnara, E.C., Sartori, I.A., Lima, J.G., Bender, R.J., and Schwarz, S.F. (2011). Performance of 'Oneco' mandarin on six rootstocks in South Brazil. Pesq. Agropec. Bras. 46, 406-411. https://doi.org/10.1590/S0100-204X2011000400010.

IBGE. Instituto Brasileiro de Geografia e Estatística (2012). Sistema IBGE de Recuperação Automática Brazil. http://www.sidra.ibge.gov. $\mathrm{br} / \mathrm{bda} /$ tabela/protabl.asp?c=1613\&z=p\&o=18\&i=p.

Jeronimo, R.F., and Kanesiro, M.A.B. (2000). Efeito da associação de armazenamento sob refrigeração e atmosfera modificada na qualidade de mangas 'Palmer'. Rev. Bras. de Fruticult. 22, 237-243.

Ko, K.C., Kim, C.S., Lee, N.H., Lee, S.P., and Moon, D.K. (2000). Determination of $\alpha$-cryptoxanthin in peel and flesh of citrus fruits produced in Cheju Island. Food Sci. Biotechnol. 9, 288-291. https:// doi.org/10.1104/pp.114.255711.

Lima, L.C., Boas, E.V.B.V., Reis, J.M.R., and Chitarra, A.S.B. (1999). Qualidade dos frutos de tangerineiras 'Ponkan' (Citrus reticulata Blanco), armazenados sob temperatura ambiente. Rev. Univ. de Alfenas 5, 27-31. 
Lin, S.D., and Chen, A.O. (1995), Major carotenoids in juices of 'Ponkan' mandarin and 'Liucheng' orange. J. Food Biochem. 18, 273293. https://doi.org/10.1111/j.1745-4514.1994.tb00502.x.

Malgarim, M.B., Cantillano, R.F.F., Oliveira, R.P., and Treptow, R.O. (2008). Qualidade pós-colheita de citros 'Nova' em diferentes períodos de armazenamento e comercialização. Rev. Bras. de Agrociência 14, 19-23.

Mourão-Filho, F.A.A., Pio, R., Mendes, B.M.J., Azevedo, F.A., Schinor, E.H., Entelmann, F.A., Alves, A.S.R., and Cantuarias-Aviles, T.E. (2008). Evaluation of citrus somatic hybrids for tolerance to Phytophthora nicotianae and citrus tristeza virus. Sci. Hortic. 115, 301-308. https://doi.org/10.1016/j.scienta.2007.10.004.

Pereira, M.E.C., Cantillano, F.F., Gutierez, A.S.D., and Almeida, G.V.B. (2006). Procedimentos pós-colheita na produção integrada de citros. (Cruz das Almas, Bahia, Brasil: Embrapa Mandioca e Fruticultura Tropical)

Pio, R.M. (2003). Tangerinas para o verão. Laranja 14, 539-549.

Pompeu Jr., J., Laranjeira, F.F., and Blumer, S. (2002). Laranjeiras 'Valência' enxertadas em híbridos de trifoliata. Sci. Agric. 59, 93-97. https://doi.org/10.1590/S0103-90162002000100014.

Saunt, J., (1990). Citrus Varieties of the World (Norwich, England: Sinclair Int., Ltd.).

Schäfer, G., Panzenhagen, N.V., Sartori, I.A., Schwarz, S.F., and Koller, O.C. (2001). Produção e desenvolvimento da tangerineira 'Montenegrina' propagada por enxertia e estaquia, no Rio Grande do Sul. Rev. Bras. de Fruticult. 23, 668-672. https://doi.org/10.1590/ S0100-29452001000300045.

Schinor, E.H., Yaly, M.C., Bastianel, M., and Machado, M.A. (2013). 'Sunki' mandarin vs. Poncirus trifoliata hybrids as rootstocks for Pera sweet orange. J. Agric. Sci. 5, 190-200. https://doi.org/10.5539/jas. v5n6p190.

Stenzel, N.M.C., Neves, C.S.V.J., Gomes, J.C., and Medina, C.C. (2003). Performance of 'Ponkan' mandarin on seven rootstocks in Southern Brazil. Hortscience 38, 176-178.

Stuchi, E.S., Donadio, L.C., and Sempionato, O.R. (2003). Performance of Tahiti lime on Poncirus trifoliata var. monstrosa Flying Dragon in four densities. Fruits 58, 13-17. https://doi.org/10.1051/ fruits:2002032

Sumida, T., Hamada, S., Azuma, Y., Ogawa, H., and Tada, M. (1999). Change of total carotenoid and $\alpha$-cryptoxanthin contents of satsuma mandarin (Citrus unshiu Marc.) juice caused by heating, illumination and storage. Nippon Shokulin Kagaku Gakkaishi 6, 106-110.

Toniolli, C.B., Koller, O.C., and Schwarz, S.F. (1993). Crescimento vegetativo de laranjas 'Valência' e tangereiras 'Montenegrina' propagada por estaquia e por enxertia. Rev. Brasil. de Fruticult. 15, 49-53.

Received: Feb. 2, 2016

Accepted: Jul. 18, 2017 